\title{
Bioenergy Production from Anaerobic Co-Digestion of Sewage Sludge and Abattoir Wastes
}

\author{
Dida Aberra, Fekadu Fufa \\ School of Civil and Environmental Engineering, Jimma Institute of Technology, Jimma University, Oromia, \\ Ethiopia \\ Email: didabera@gmail.com, fekaduff2010@gmail.com
}

Received 28 March 2016; accepted 17 July 2016; published 20 July 2016

Copyright (C) 2016 by authors and Scientific Research Publishing Inc.

This work is licensed under the Creative Commons Attribution International License (CC BY). http://creativecommons.org/licenses/by/4.0/

(c) (7) Open Access

\begin{abstract}
Energy is the pillar of human economic development. Several energy sources, renewable and nonrenewable, have been exploited to assure and sustain the need for sustainable development. However, depletion of non-renewable energy sources forced researchers to search for alternative cost effective and environmental friendly energy sources. Thus, conversion of waste materials into energy has obtained considerable attention. In line with this, the aim of this study is to investigate the improvement of bio-energy production through anaerobic digestion of mixture of wastes from sewage sludge and abattoir sources. The abattoir waste is functioned as a co-substrate. Laboratory scale batch anaerobic co-digestion of the waste is carried out under mesophilic condition for 20 days. Sewage Sludge (SS) alone, and different mix ratios of SS to Abattoir Waste (AW) were analyzed for bioenergy production. Besides, the nutrient values and reduction in volume of the sewage after digestion were determined. The results show that methane productions of $33.8 \%, 48.3 \%$ and $56.9 \%$ were obtained for SS alone and for SS:AW mix ratios of $4: 1$ and 3:2, respectively. The nutrient values of the slurry increased as mix ratio decreased due to the increase in the amount of $\mathrm{AW}$. The obtained results indicate that bio-energy production can be improved through co-digestion of SS using AW as a co-substrate; thus warranting further investigation for the practical application in the energy production.
\end{abstract}

\section{Keywords}

Bio-Energy, Anaerobic Co-Digestion, Abattoir Wastes, Sewage Sludge

\section{Introduction}

Treatment of municipal wastewater results in the generation of large amounts of sewage sludge. Major part of

How to cite this paper: Aberra, D. and Fufa, F. (2016) Bioenergy Production from Anaerobic Co-Digestion of Sewage Sludge and Abattoir Wastes. Advances in Chemical Engineering and Science, 6, 281-287. 
the dry matter (cake) content of this sludge consists of nontoxic organic compounds, which is a combination of primary sludge and secondary (microbiological) sludge. There are many sludge-management options in which resource recovery (energy and organic fertilizer) through anaerobic process is one of the key treatment steps [1].

Anaerobic digestion is a microbiological process that converts the chemically complex organic biomass into methane, carbon dioxide, and in offensive humus like material. The reactions occur in a closed tank or digester that is anaerobic - that is, devoid of oxygen. The conversion takes place through a series of reactions.

Anaerobic digestion of biomass under mesophilic condition has been a widely used technique in the efficient management of biomass wastes of all kinds and in the simultaneous recovery of useful resources, such as energy and soil conditioner [2]-[4]. In addition, utilizing methane produced at the treatment site plays a great role in minimizing the release of greenhouse gas to the atmosphere.

Anaerobic digestion has many environmental benefits including the production of a renewable energy carrier, the possibility of nutrient recycling and reduction of waste volumes [5]-[7]. Many kinds of organic waste have been digested anaerobically in a successful way, such as sewage sludge, industrial waste, slaughterhouse waste, fruit and vegetable waste, manure and agricultural biomass.

Much attention has been focused on the improvement of methane production in order to upgrade the role in stabilizing the sludge and to produce a feasible bioenergy power plant [8]. An interesting option for improving methane yields is co-digestion. This is a process where resource recovery can be optimized by improving the nutrient and organic content of substrates to be used in anaerobic digester.

Nowadays many successful efforts have been reported in co-digestion of sewage sludge with several other substrates, such as the source-sorted organic fraction of municipal solid waste [9]-[11], confectionery waste [12], sludges from the pulp and paper industry [13], coffee waste [14] and grease-trap sludge from meat processing plants [15] [16], have been reported. The use of co-substrates usually improves the biogas yields from anaerobic digester due to positive synergisms established in the digestion medium and the supply of missing nutrients by the co-substrates [17].

Therefore, the aim of this study is to investigate, under laboratory set up, improvement of the recovery of resources (bioenergy and biofertilizer) through anaerobic co-digestion of sewage sludge (SS) and abattoir waste (AW) under mesophilic condition at $35^{\circ} \mathrm{C}$. Rate of production of biogas was also investigated under different SS:AW mix ratios.

\section{Materials and Methods}

\subsection{Materials}

Different analytical instruments were employed to measure different parameters. Glass bottle, filter papers (DP-70, $47 \mathrm{~mm}$ ), N840.3FT.18 type vacuum filter, crucibles, folks, Jenway model 3510 digital pH meter, Beschickung-Loading model 100 - 800 type oven, dissector, armfield W8 Anaerobic Digester, magnetic stirrer, rubber hose, incubator, muffle furnace, measuring cylinder, sterile plastic Petri dish, hand lens, lids, GA-45 gas analyzer, Lovibond oxidirect TS 606/4-I type, HI 839800 COD Hanna Reactor, Tedlar gas sampling bag, model NOV AA 400 AAS and JD 210-4 mode3l No. weighing scale were are few to mention. Analytical grade reagents were used throughout the study. The feed for the reactor (SS, inoculums and AW) were obtained from Kaliti Waste Water Treatment Plant, nearby residential biogas plant and Addis Ababa Abattoirs Enterprise respectively. Characteristics of the feeds and their different mix ratio were analyzed before and after digestion and results were recorded (Tables 1-4).

\subsection{Experimental Setup}

Series of batch experiments were carried out in the experimental set-up consisted of a jacketed glass reactor with controlled temperature under mesophilic condition $\left(35^{\circ} \mathrm{C}\right)$ with a volume of 5 liters laboratory scale cylindrical anaerobic digester W8 issue 3 arm field model, sealed with a rubber stopper. A magnetic stirrer was used for mixing. Digestion period of 20 days was used in the laboratory for each set up. Biogas production was determined by water displacement, methane and carbon dioxide in biogas measured by GA-45, gas analyzer.

The temperature of reactor was controlled by an electric heating mat wrapped around the external wall. The gas off-take from the reactor was taken to a volumetrically calibrated collector vessel operating by water displacement. A constant head, liquid seal device ensures that the gas pressure in the reactor is maintained at a con- 
stant value throughout the experiment.

Liquid and gas sampling points are located at all strategic points around the reactors. Non-return valves and liquid seal syphon breaks were included in the process pipe work to ensure each reactor operates at a constant volume without the entrance of air or the danger of accidental symphonic action. The equipment was mounted on a vacuum formed plastic base with an integral drain channel to cope with spillages and wash down.

Amount of biogas produced from only sewage sludge, and co-digestion of 4:1 and 3:2 (the first value is for SS and the second one is for AW) were determined through water displacement and the gases were collected using Tedlar gas sampling bag and subsequently analyzed by GA-45 (Geotechnical Instrument).

Table 1. Composition of SS before digestion (mean \pm SD).

\begin{tabular}{|c|c|c|}
\hline Parameter & Unit & Values \\
\hline $\mathrm{pH}$ & & $7.47 \pm 0.35$ \\
\hline TS & $\mathrm{mg} / \mathrm{l}$ & $39,831 \pm 3987.6$ \\
\hline VS & $\mathrm{mg} / \mathrm{l}$ & $27,043 \pm 4956$ \\
\hline COD & $\mathrm{mg} / \mathrm{l}$ & $32,872 \pm 2600.5$ \\
\hline BOD5 & $\mathrm{mg} / \mathrm{l}$ & $12,600 \pm 3567$ \\
\hline $\mathrm{TN}$ & $\mathrm{mg} / \mathrm{l}$ & $49.6 \pm 8.3$ \\
\hline $\mathrm{TP}$ & $\mathrm{mg} / \mathrm{l}$ & $78.8 \pm 9.4$ \\
\hline TK & $\mathrm{mg} / \mathrm{l}$ & $231.7 \pm 13.25$ \\
\hline $\mathrm{Cu}$ & $\mathrm{mg} / \mathrm{l}$ & $0.172 \pm 0.0741$ \\
\hline $\mathrm{Ni}$ & $\mathrm{mg} / \mathrm{l}$ & $0.1417 \pm 0.0572$ \\
\hline $\mathrm{Cr}$ & $\mathrm{mg} / \mathrm{l}$ & $0.00519 \pm 0.0032$ \\
\hline $\mathrm{Pb}$ & $\mathrm{mg} / \mathrm{l}$ & $<0.0001$ \\
\hline $\mathrm{Cd}$ & $\mathrm{mg} / \mathrm{l}$ & Nil \\
\hline $\mathrm{Zn}$ & $\mathrm{mg} / \mathrm{l}$ & $0.3241 \pm 0.082$ \\
\hline $\mathrm{TC}$ & MPN/100 ml & $20 \times 10^{6}$ \\
\hline FC & MPN/100 ml & $12 \times 10^{6}$ \\
\hline Ascaris & No./l & $18,000-39,000$ \\
\hline Hook worm & No./l & $0-3800$ \\
\hline
\end{tabular}

MPN = Most Probable Number.

Table 2. Composition of AW before digestion (mean $\pm \mathrm{SD}$ ).

\begin{tabular}{ccc}
\hline Parameters & Unit & Values \\
\hline $\mathrm{pH}$ & $\mathrm{mg} / \mathrm{l}$ & $6.62 \pm 0.47$ \\
$\mathrm{TS}$ & $\mathrm{mg} / \mathrm{l}$ & $10,823 \pm 5656.85$ \\
$\mathrm{VS}$ & $\mathrm{mg} / \mathrm{l}$ & $2529.32 \pm 638$ \\
$\mathrm{COD}$ & $\mathrm{mg} / \mathrm{l}$ & $6950 \pm 636.40$ \\
BOD5 & $\mathrm{mg} / \mathrm{l}$ & $3975 \pm 775$ \\
$\mathrm{TN}$ & $\mathrm{mg} / \mathrm{l}$ & $171.5 \pm 26.16$ \\
$\mathrm{TP}$ & & $69.5 \pm 21.72$ \\
\hline
\end{tabular}


Table 3. Characteristics of the feedstock before digestion (mean \pm SD).

\begin{tabular}{ccccc}
\hline Parameters & Unit & SS alone & \multicolumn{2}{c}{ SS:AW ratio } \\
\cline { 3 - 4 } pH & & $7.47 \pm 0.35$ & $7.62 \pm 0.23$ & $3: 2$ \\
TS & $\mathrm{mg} / \mathrm{l}$ & $39,831 \pm 3987.6$ & $35,397 \pm 3145.7$ & $31,148 \pm 2517$ \\
VS & $\mathrm{mg} / \mathrm{l}$ & $27,043 \pm 4956$ & $23,199 \pm 2053$ & $19,327 \pm 1678.4$ \\
COD & $\mathrm{mg} / \mathrm{l}$ & $32,872 \pm 2600.5$ & $28,203 \pm 1609.7$ & $25,607 \pm 2345$ \\
BOD5 & $\mathrm{mg} / \mathrm{l}$ & $12,600 \pm 3567$ & $11,222.9 \pm 735.6$ & $9895 \pm 1507.2$ \\
TN & $\mathrm{mg} / \mathrm{l}$ & $49.60 \pm 8.30$ & $84.5 \pm 11.30$ & $91.10 \pm 3.3$ \\
TP & $\mathrm{mg} / \mathrm{l}$ & $78.80 \pm 9.40$ & $67.61 \pm 4.10$ & $83.02 \pm 7.4$ \\
TK & $\mathrm{mg} / \mathrm{l}$ & $231.7 \pm 13.25$ & $107.13 \pm 21.08$ & $99.87 \pm 15.16$ \\
Ascaris & No/l & $18,000-39,000$ & $14,000-32,000$ & $10,000-26,000$ \\
Hook worm & No/l & $0-3800$ & $0-2400$ & Nil \\
\hline
\end{tabular}

Table 4. Characteristics of feedstock after digestion (mean \pm SD).

\begin{tabular}{|c|c|c|c|c|}
\hline \multirow{2}{*}{ Parameters } & \multirow{2}{*}{ Unit } & \multirow{2}{*}{ SS alone } & \multicolumn{2}{|c|}{ SS:AW ratio } \\
\hline & & & $4: 1$ & $3: 2$ \\
\hline $\mathrm{pH}$ & & $7.93 \pm 0.106$ & $7.67 \pm 0.230$ & $7.4 \pm 0.004$ \\
\hline TS & $\mathrm{mg} / \mathrm{l}$ & $25,965 \pm 1025$ & $21,592.2 \pm 451.7$ & $18,880.6 \pm 123.5$ \\
\hline VS & $\mathrm{mg} / \mathrm{l}$ & $18,389.2 \pm 1614.27$ & $14,594.6 \pm 1307$ & $11,460.9 \pm 605.32$ \\
\hline COD & $\mathrm{mg} / \mathrm{l}$ & $10,891.6 \pm 674.16$ & $8172.9 \pm 827.13$ & $7228.1 \pm 214.6$ \\
\hline BOD5 & $\mathrm{mg} / \mathrm{l}$ & $2898 \pm 234.34$ & $2581.26 \pm 267$ & $2275.8 \pm 513.26$ \\
\hline $\mathrm{TN}$ & $\mathrm{mg} / \mathrm{l}$ & $46.6 \pm 6.82$ & $62.6 \pm 0.062$ & $65.87 \pm 0.023$ \\
\hline $\mathrm{TP}$ & $\mathrm{mg} / \mathrm{l}$ & $68.6 \pm 4.65$ & $63.8 \pm 0.042$ & $76.349 \pm 0.082$ \\
\hline TK & $\mathrm{mg} / \mathrm{l}$ & $111.4 \pm 8.67$ & $69.2 \pm 0.026$ & $68.1 \pm 0.034$ \\
\hline Ascaris & No/l & $18,000-39,000$ & $14,000-32,000$ & $10,000-26,000$ \\
\hline Hook worm & No/l & $0-3800$ & $0-2400$ & Nil \\
\hline $\mathrm{Cu}$ & $\mathrm{mg} / \mathrm{l}$ & $0.1602 \pm 0.068$ & $<0.0001$ & $<0.0001$ \\
\hline $\mathrm{Ni}$ & $\mathrm{mg} / \mathrm{l}$ & $0.0786 \pm 0.084$ & $0.0920 \pm 0.018$ & $0.1863 \pm 0.048$ \\
\hline $\mathrm{Cr}$ & $\mathrm{mg} / \mathrm{l}$ & $0.0139 \pm 0.023$ & $<0.0001$ & $<0.0001$ \\
\hline $\mathrm{Pb}$ & $\mathrm{mg} / \mathrm{l}$ & $0.0892 \pm 0.056$ & $0.0356 \pm 0.023$ & $<0.0001$ \\
\hline $\mathrm{Cd}$ & $\mathrm{mg} / \mathrm{l}$ & $<0.0001$ & $<0.0001$ & $<0.0001$ \\
\hline $\mathrm{Zn}$ & $\mathrm{mg} / \mathrm{l}$ & $0.748 \pm 0.067$ & $0.6627 \pm 0.030$ & $0.5777 \pm 0.031$ \\
\hline TC & MPN/100 ml & $32 \times 10^{4}$ & $12 \times 10^{4}$ & $6 \times 10^{4}$ \\
\hline FC & MPN/100 ml & $14 \times 10^{4}$ & $7 \times 10^{4}$ & $2 \times 10^{4}$ \\
\hline
\end{tabular}


Physicochemical and biological characteristics (pH, TS, VS, BOD5, COD, heavy metals (Cd, Cr, Cu, Pb, Ni, and Zn), TKN, total phosphorus, potassium, and pathogens) of SS and different mixtures of SS and abattoirs wastes were analyzed before and after digestion.

Total solid was estimated from weight loss up on evaporation at $105^{\circ} \mathrm{C}$ for 24 hours (Standard Method Procedure $2540 \mathrm{~B}$ ). Total volatile solid content was estimated from weight loss upon ignition at $550^{\circ} \mathrm{C}$ for 2 hours in muffle furnace (Standard Method Procedure $2540 \mathrm{E}$ ) and $\mathrm{pH}$ was measured by Jenway model 3510 digital pH meter.

\section{Results}

The physiochemical and bacteriological characteristics of the SS and AW and their different mix ratios used were determined and the experimental results are given in Tables 1-4.

\section{Discussion}

\subsection{Rate of Biogass Production}

The amount of biogas production was increased as the mix ratio increased. The cumulative biogas produced during the experimental period for the digestion of the feed stocks is given in Figure 1. The results show that 0.51, 0.85 and $0.93 \mathrm{~m}^{3} / \mathrm{d} / \mathrm{m}^{3}$ biogas with $33.8 \%, 48.3 \%$ and $56.9 \%$ methane were produced from SS alone, 4:1 and 3:2 mix ratios of SS to AW, respectively. The relative composition of the gases found in the biogas produced from SS alone and different mix ratios were also analyzed and the results are presented in Figure 2.

\subsection{Characteristics of Feedstock after Digestion}

Reductions in physicochemical properties analyzed in the study were observed. Accordingly, percentage reduction of TS $38 \%$, 39\% and $39.4 \%$; VS $32 \%, 37.1 \%$ and $40.7 \%$; and COD $70 \%, 71 \%$, and $71.8 \%$, were obtained from the digestion of SS alone, 4:1 and 3:2 mix ratio respectively (Figure 3). This shows that there is a slight increase in the removal efficiency of parameters understudy as the mix ratio of SS and abattoir waste increases. Besides, the digestion significantly reduce the coliform bacteria: $98.6 \%$ for fecal coliform and $98.4 \%$ for total coliform; but not the helminthes eggs, indicate that the digested sludge cannot be directly used for agricultural application without further treatment like sun drying which is less expensive than pasteurization to completely inactivate the remaining bacteria and helminthes eggs. It was observed complete removal of helminthes eggs after drying the digested sludge on direct sun light exposure for one month. WHO reports the same situation of complete removal of parasite when the fermented slurry is dried in the sun [18].

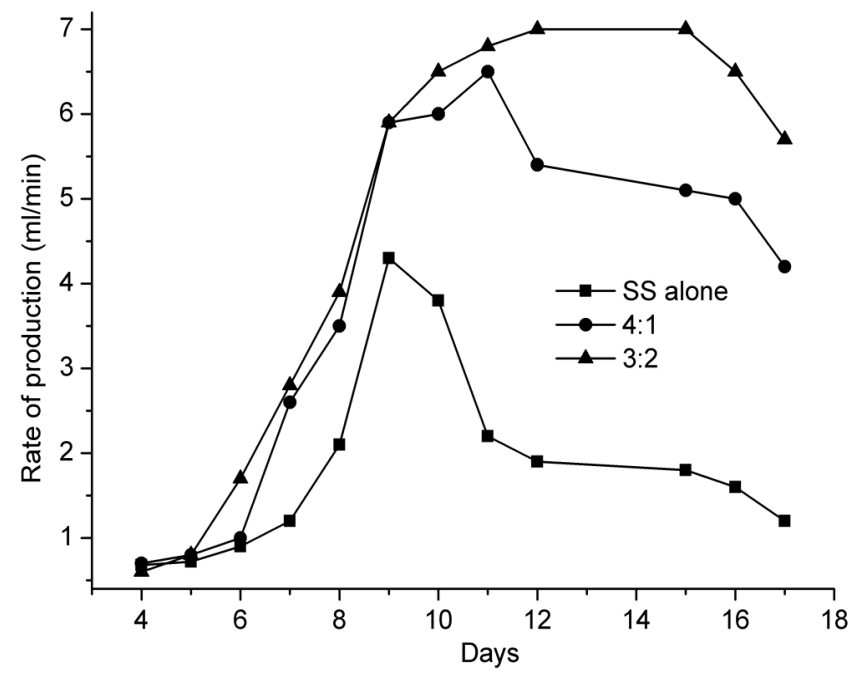

Figure 1. Rate of production of biogas from SS alone and different mix ratios. 


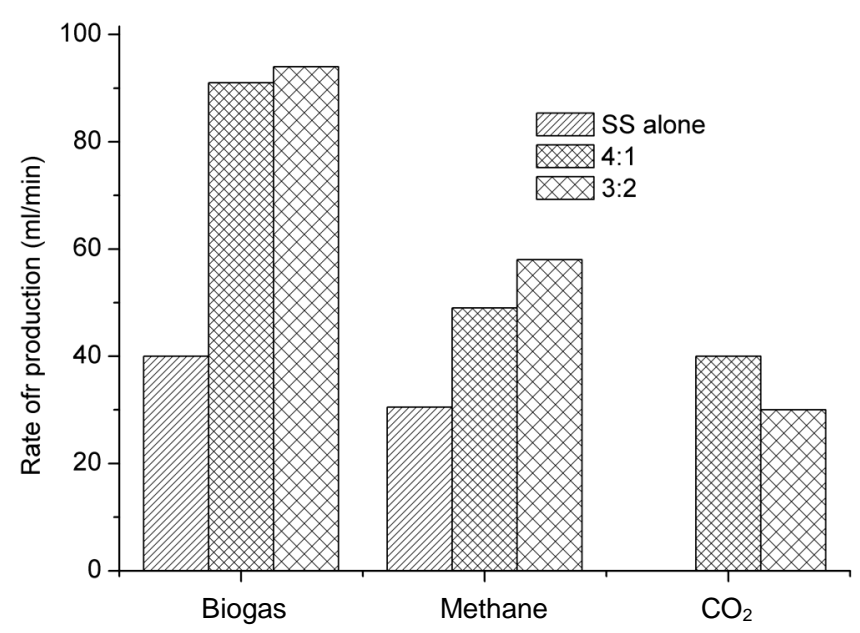

Figure 2. Composition of the biogas at different mix ratio.

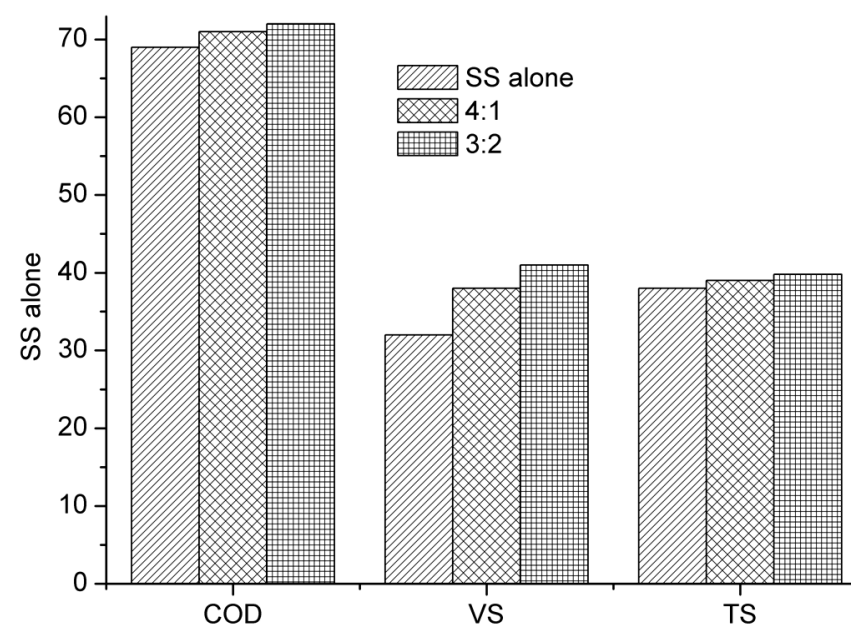

Figure 3. Reductions in physicochemical parameters.

\section{Conclusion}

SS wastes are loaded by organic portion, which contains the most valuable elements, carbon, for the formation of methane; whereas abattoir effluents contain excess valuable nutrients for anaerobes, which lead the co-digestion of the two wastes to high degree of methanization process. The mix ratio 3:2 was observed to produce the maximum quantity of biogas with the maximum percentage of methane. This shows that co-digestion of SS and AW enhances the quality and quantity of methane yield. The average percentage removal of TS, VS and COD increases with the mix ratio of the SS and its co-substrate (AW). The experimental results show that using anaerobic digestion of SS considerable amount of methane (annually 52,320 $\mathrm{m}^{3}$ methane can be produced from the treatment site) can be captured from being emitted into atmosphere to prevent greenhouse effect. As observed in this study, biogas generation rate was increased with the mix ratio of AW with SS. This can be due to increase in dilution of the mixture, which can facilitate sympathetic environment for anaerobes or because of the addition of nutrients to the SS. Therefore, AW can be used as a co-substrate in the anaerobic digestion of sludge waste to increase the recovery of resources from waste.

\section{Acknowledgements}

The first author would like to thank laboratory staffs of Addis Ababa Institute of Technology and Addis Ababa Environmental Protection Agency. Besides, the cooperation of workers at Kaliti Wastewater Stabilization Pond and Addis Ababa Abattoirs Enterprise was immense. 


\section{References}

[1] Rulkens, W. (2008) Sewage Sludge as a Biomass Resource for the Production of Energy: Overview and Assessment of the Various Options. Energy and Fuels, 22, 9-15. http://dx.doi.org/10.1021/ef700267m

[2] Braun, R., Brachtl, E. and Grasmug, M. (2003) Codigestion of Proteinaceous Industrial Waste. Applied Biochemistry and Biotechnology, 109, 139-153. http://dx.doi.org/10.1385/ABAB:109:1-3:139

[3] Hansen, K.H., Angelidaki, I. and Ahring, B.K. (1998) Anaerobic Digestion of Swine Manure: Inhibition by Ammonia. Water Research, 32, 5-12. http://dx.doi.org/10.1016/S0043-1354(97)00201-7

[4] de Baere, L. (2004) The Role of Anaerobic Digestion in the Treatment of MSW: State of-the-Art. Proceedings of 10th World Congress of Anaerobic Digestion, Vol. 1, 395-400.

[5] Ghosh, S., Conrad, J.R. and Klass, D.L. (1975) Anaerobic Acidogenesis of Wastewater Sludge. Journal (Water Pollution Control Federation), 47, 30-45.

[6] Hawkes, F.R. and Hawkes, D.L. (1987) Anaerobic Digestion. In: Bu’lock, J. and Kristiansen, B., Eds., Basic Biotechnology, Academic Press, London, 337-358.

[7] van Lier, J.B., et al. (2001) New Perspectives in Anaerobic Digestion. Water Science and Technology, 43, 1-18.

[8] Fountoulakis, M.S., Petousi, I. and Manios, T. (1849) Co-Digestion of Sewage Sludge with Glycerol to Boost Biogas Production. Waste Management, 30, 1849-1853. http://dx.doi.org/10.1016/j.wasman.2010.04.011

[9] Del Borghi, A., Converti, A., Palazzi, E. and Del Borghi, M. (1999) Hydrolysis and Thermophilic Anaerobic Digestion of Sewage Sludge and Organic fRaction of Municipal Solid Waste. Bioprocess Engineering, 20, 553-560. http://dx.doi.org/10.1007/s004490050628

[10] Gómez, X., Morán, A., Cuetos, M.J. and Sánchez, M.E. (2006) The Production of Hydrogen by Dark Fermentation of Municipal Solid Wastes and Slaughterhouse Waste: A Two-Phase Process. Journal of Power Sources, 157, 727-732. http://dx.doi.org/10.1016/j.jpowsour.2006.01.006

[11] Sosnowski, P., Wieczorek, A. and Ledakowicz, S. (2003) Anaerobic Co-Digestion of Sewage Sludge and Organic Fraction of Municipal Solid Wastes. Advances in Environmental Research, 7, 609-616. http://dx.doi.org/10.1016/S1093-0191(02)00049-7

[12] Lafitte-Trouqué, S. and Forster, C.F. (2000) Dual Anaerobic Co-Digestion of Sewage Sludge and Confectionery Waste. Bioresource Technology, 71, 77-82. http://dx.doi.org/10.1016/S0960-8524(99)00043-7

[13] Einola, J.K., Luostarinen, S.A., Salminen, E.A. and Rintala, J.A. (2001) Screening for an Optimal Combination of Municipal and Industrial Wastes and Sludges for Anaerobic Co-Digestion. Proceedings of the 9th World Congress, Anaerobic Digestion 2001, Anaerobic Conversion for Sustainability, Antwerpen, 2-6 September 2001, 357-362.

[14] Neves, L., Oliveira, R. and Alves, M.M. (2006) Anaerobic Co-Digestion of Coffee Waste and Sewage Sludge. Waste Management, 26, 176-181. http://dx.doi.org/10.1016/j.wasman.2004.12.022

[15] Davidsson, Å., Lövstedt, C., la Cour Jansen, J., Gruvberger, C. and Aspegren, H. (2008) Co-Digestion of Grease Trap Sludge and Sewage Sludge. Waste Management, 28, 986-992. http://dx.doi.org/10.1016/j.wasman.2007.03.024

[16] Luostarinen, S., Luste, S. and Sillanpaa, M. (2009) Increased Biogas Production at Wastewater Treatment Plants through Co-Digestion of Sewage Sludge with Grease Trap Sludge from a Meat Processing Plant. Bioresource Technology, 100, 79-85. http://dx.doi.org/10.1016/j.biortech.2008.06.029

[17] Schmelz, K.-G. (1999) Co-Fermentation of Biogenic Waste in Sewage Treatment Plants. Proceedings of ORBIT 99, Federal Republic of Germany, Weimar, 2-4 September 1999, 187-195.

[18] WHO (2006) Guidelines for the Safe Use of Wastewater, Excreta and Grey Water. Vol. 4, Excreta and Grey Water Use in Agriculture. WHO, Geneva. 


\section{Submit or recommend next manuscript to SCIRP and we will provide best service for you:}

Accepting pre-submission inquiries through Email, Facebook, LinkedIn, Twitter, etc.

A wide selection of journals (inclusive of 9 subjects, more than 200 journals)

Providing 24-hour high-quality service

User-friendly online submission system

Fair and swift peer-review system

Efficient typesetting and proofreading procedure

Display of the result of downloads and visits, as well as the number of cited articles

Maximum dissemination of your research work

Submit your manuscript at: http://papersubmission.scirp.org/ 